\title{
Worldwide or Territorial Approach for Individual Income Tax-Which is More Prevalent?
}

\author{
Connie Shum, Jack Fay \\ Pittsburg State University, Pittsburg, USA \\ Gladie Lui \\ Lingnan University, TuenMun, Hong Kong
}

\begin{abstract}
For individuals who are contemplating relocating, how their income will be taxed might be an important factor when deciding whether or not to take up residence in another country. Two income approaches are commonly used around the globe. Worldwide income approach (also known as a global tax system) taxes income from whatever source derived. Territorial income approach taxes only income earned within the country’s borders. Using information collected from PricewaterhouseCoopers' website $^{1}$ that provides information on tax systems used in countries around the world, this paper examines which countries apply worldwide or global income approach and which employ territorial approach to determine the legitimate source of taxable income. The research focuses on countries within: (1) Americas; (2) Asia/Pacific Basin; (3) Europe; and (4) Africa/Middle and Near East. Based on the information collected and presented in this paper, the worldwide approach is much more prevalent (104 countries) than the territorial approach (30 countries). This paper also investigates any specific rules that a particular country has in relation to income to be taxed and residency versus non-residency status of the taxpayers. There appears to be an abundant spectrum of rules relating to residency and domicile for tax purposes among the countries.
\end{abstract}

Keywords: individual income tax, global individual income tax, worldwide/territorial income approach

\section{Introduction}

Keeping up with tax laws and being aware of tax trends is very important since most people in most countries are liable for some form of income taxes either as individuals or as dependents. As globalization and internationalization of markets become more prevalent, understanding tax laws worldwide has become even more important, especially for those who might be relocating to another country either for work or for personal reasons. How income is taxed might be an important factor when deciding whether or not to take up residence in a country.

Most countries derive most of their revenues from residents. In some cases, non-residents are also subject to taxes. Two different approaches are commonly used in the world. Worldwide income approach (also known as global tax system) taxes income from whatever source derived. For example, the United States requires that

Connie Shum, Professor of Finance, Department of Economics and Finance, Pittsburg State University. Email: cshum@pittstate.edu.

Jack Fay, Professor Emeritus, Department of Accounting, Pittsburg State University.

Gladie Lui, Professor of Accounting, Department of Accountancy, Lingnan University.

${ }^{1}$ Retrieved from http://taxsummaries.pwc.com/ID/tax-summaries-home. 
income from both U.S. and foreign sources be reported for individual income tax purposes. Many countries, especially industrialized nations, utilize some type of worldwide income approach. Other countries, on the other hand, use territorial income approach in which only income earned within their borders is normally reported for federal taxability.

Countries utilizing the worldwide approach, such as the U.S., realize that their citizens may be paying income taxes also in the countries in which they have earned income. Therefore, their tax laws generally provide means to eliminate or reduce the double taxation that arises when income is subject to tax in multiple jurisdictions. The U.S., for instance, provides a foreign tax credit, a foreign tax itemized deduction, a foreign earned income exclusion for U.S. citizens and residents who work abroad, and some tax treaty provisions.

Keeping track of tax laws in other countries is important not only to those who are considering relocating to or conducting businesses in another country. Universities have been internationalizing their curriculum. International business courses/contents are a regular part of what is being taught in the classroom. Having current information on tax laws around the world would be very useful to students as well as educators.

Some research has been published on topics related to individual income tax. However, only Fay (2002) as well as Shum, Fay, and Lui (2017) compared individual income tax rates in various countries. Fay (2002) reported tax rates of countries around the world for the period in 2002. Shum et al. (2017) updated Fay's study. In addition to tax rates in 2016, information on non-business deductions allowed is also reported. Other studies examine other aspects of individual income tax, including estimating tax rates for 12 OECD countries (Wagstaff, van Doorslaerb, van der Burgb, Calongec, Christiansend, Citoni, ..., \& Winkelhake, 1999), examining the effects certain factors have on individual income tax rates (Mendoza, Razin, \& Tesar, 1994), and describing the trends of national tax systems (Sabirianova, Buttrick, \& Duncan, 2009). This study fills the gap by providing a most up-to-date report on how countries around the world tax their residents and non-residents.

The purpose of this study is to examine which countries apply the worldwide or global income approach and which employ the territorial approach. Information is obtained from PricewaterhouseCoopers' website (http://taxsummaries.pwc.com/ID/tax-summaries-home). A secondary objective of this study is to investigate any specific rules that a particular country has in relation to income to be taxed and residency versus non-residency status of the taxpayers.

To make some comparisons on a regional basis, the world is categorized into four sections: Americas, Asia/Pacific Basin, Europe, and Africa/Middle and Near East. The next section of this paper shows which income approach is used by each country in each region and describes briefly specific rules relating to the reporting and taxability of income for individuals.

\section{Tax Methods Used by Countries}

PricewaterhouseCoopers maintains a website (http://taxsummaries.pwc.com/ID/tax-summaries-home) that provides information on tax systems used in countries around the world. The website provides details on both individual income tax and corporate tax. Information presented below is gathered from the sections on personal income tax.

\section{Americas}

Antigua and Barbuda: Territorial. Residents and non-residents are taxed on income sourced from Antigua and Barbuda. 
Argentina: Worldwide. Taxes based on worldwide income apply to residents and foreign beneficiaries. Non-residents are taxed only on their Argentine-source income. Non-residents include foreign nationals assigned to work in Argentina for less than five years. Foreign beneficiaries include individuals who work temporarily in Argentina for less than six months in a calendar year.

Bahamas: None. There is no income tax.

Barbados: Worldwide. A taxpayer who is both a resident and is domiciled in Barbados is taxed on worldwide income. A taxpayer who is a resident but not domiciled in Barbados is taxed on income derived from Barbados and from any other sources outside Barbados to the extent that benefit is received in the country. A non-resident is taxed only on income arising in Barbados. An individual spending more than 182 days in Barbados in a calendar year is considered resident.

Bermuda: None. There is no income tax.

Bolivia: Territorial. Bolivian-source income is subject to tax for non-resident aliens. Citizenship and domicile have no bearing on the tax base.

Brazil: Worldwide. Residents are taxed on their worldwide income. Non-residents are taxed only on Brazilian-source income. The income source is determined by the taxpayer's domicile regardless of where the work is performed. Foreign nationals present in Brazil for 183 days or more within a 12-month period are deemed residents.

Canada: Worldwide. Residents are taxed on their worldwide income. Foreign tax credits and deductions based on foreign tax treaties provide relief from double taxation. Non-residents are subject to income tax on Canadian employment, proprietorship, and capital gains. Part-time residents are taxed on their worldwide income only for the period in which they are Canadian residents.

Cayman Islands: None. There is no income tax.

Chile: Worldwide. Chilean residents and domiciles are taxed on their worldwide income. Foreigners who work in Chile are taxed only on their income earned in Chile during their first three years in the country. After three years, they are taxed on their worldwide income.

Colombia: Worldwide. Fiscal residents (national or foreign) are taxed on worldwide income. Non-residents (national or foreign) are taxed on Columbian-source income. Individuals who remain in Colombia for an aggregate period of 183 days or more within a period of 365 consecutive days are considered fiscal residents.

Costa Rica: Territorial. Regardless of resident status, taxpayers are levied income taxes on all income earned in Costa Rica.

Commonwealth of Dominica: Worldwide. An individual who is resident and also ordinary resident in Dominica is taxed on worldwide income. An individual who is resident but not ordinary resident in Dominica is taxed on income sourced in Dominica and income that is remitted to Dominica. A non-resident is subject to withholding tax on income arising in Dominica. An individual whose permanent place of abode is in Dominica and is in Dominica for some period of time in the income year is considered resident. An individual who is present in Dominica for 183 days or more in an income year is also considered a resident. In addition, an individual who is resident in the immediately preceding or succeeding year of income is deemed a resident for the current income year.

Dominican Republic: Territorial. Only Dominican-source income is subject to tax for residents and non-residents. Residents are also subject to taxation on foreign investments and financial gains. Individuals remaining in Dominican Republic for more than 182 days in a calendar year are deemed residents. 
Ecuador: Territorial. Generally, citizens and foreigners are taxed only on Ecuador-source income derived from activities executed in Ecuador.

El Salvador: Territorial. Citizens, residents, and non-residents are taxed only on Salvadoran-source income.

Guatemala: Territorial. Citizens, residents, and non-residents are taxed only on Guatemalan-source income.

Guyana: Worldwide. Residents are taxed on their worldwide income. Non-residents are taxed only on income derived from Guyana. Individuals residing in Guyana for more than 182 days in a year are considered residents.

Honduras: Worldwide. Citizens and residents are taxed on income from worldwide sources. Non-residents are taxed only on income from Honduran sources. Individuals who spend more than 90 days in Honduras are considered residents.

Jamaica: Worldwide. Citizens and residents are taxed on their worldwide income. Non-residents are taxed only on Jamaican-source income. Individuals are treated as residents if any of several conditions are met.

Mexico: Worldwide. Residents are subject to tax on their worldwide income. Non-residents are taxed only on their Mexican-source income. Resident is defined as a person who has a home in Mexico. If the person has a home in another country, he/she is a tax resident in the country in which he/she has his/her center of vital interests.

Nicaragua: Territorial. Citizens and residents are taxed on income originating in Nicaragua. Income originating in Nicaragua obtained by non-residents and non-domiciled persons is determined as a percentage of gross income, and is subject to a 5\% withholding tax.

Panama: Territorial. Citizens, residents, and non-residents are taxed only on income earned from Panama sources.

Paraguay: Territorial. Residents and non-residents are taxed only on Paraguayan-source income.

Peru: Worldwide. Domiciled individuals are taxed on their worldwide income while non-domiciled taxpayers are taxed only on their Peruvian-source income. Individuals who have been in Peru for more than 182 days within a 12-month period are deemed to be domiciled in Peru.

Puerto Rico: Worldwide. Bona fide residents are taxed on their worldwide income. Non-residents are taxed only on their Puerto Rican-source income. A resident is one who has been present in Puerto Rico for 183 days or more during a calendar year.

St. Lucia: Worldwide. Residents are taxed on worldwide income. Non-residents generally are taxed only on St. Lucian-source income that is received in St. Lucia.

Trinidad and Tobago: Worldwide. Taxpayers who are domiciled and residents in Trinidad and Tobago are taxed on their worldwide income. Non-residents are taxed on income arising in Trinidad and Tobago. Individuals are considered residents if they live in the country for more than 182 days during a calendar year.

United States: Worldwide. Citizens and residents are taxed on their worldwide income. Non-resident aliens are taxed only on their U.S.-source income. Residents include green card holders and those who are present in the U.S. for at least 31 days in the current year and a total of 183 equivalent days during the current year and the previous two years (the "substantial presence test"). 
Uruguay: Territorial. Residents and non-residents are taxed only on income derived from activities developed in, property located in, or rights economically used within the Uruguayan territory. But under certain conditions, income generated outside Uruguay is subject to tax.

Venezuela: Worldwide. Residents pay taxes on their worldwide income. Foreign residents based in Venezuela pay taxes on income of national or foreign source attributable to Venezuela. Non-residents pay taxes on income originated within Venezuela.

\section{Asia/Pacific Basin}

Australia: Worldwide. Residents are taxed on their worldwide income, except for certain foreign income and gains of temporary residents. Tax credits are permitted for foreign taxes paid. Non-residents are subject to tax only on income earned in Australia and certain statutory income that is taxable on a basis other than source (e.g., certain capital gains).

Azerbaijan: Worldwide. For residents, all income earned within or outside the country is taxable, while non-residents are subject to tax only on income derived from Azerbaijan. Individuals staying in Azerbaijan for more than 182 days in a calendar year or whose center of vital interests is Azerbaijan are deemed residents.

Cambodia: Worldwide. There is no personal income tax, but residents pay a monthly salary tax on worldwide salaries. Non-residents pay a salary tax on Cambodian-source salaries. Individuals present in Cambodia for more than 182 days in a 12-month period are deemed residents.

China: Worldwide. Individuals who maintain a place of abode in China are taxed on their worldwide income. Foreign individuals are taxed in accordance with their physical presence in China. Generally, non-residents or resident foreign expatriates are taxed only on their China-source income.

Fiji: Worldwide. Residents are subject to tax on their worldwide income while non-residents are subject to tax only on their Fiji-source income. Generally, individuals who have lived in Fiji for more than 182 days in a 12-month period are considered residents.

Hong Kong: Territorial. Residents and non-residents are subject to Hong Kong-source employment income, income from an office held in Hong Kong, and income from a Hong Kong pension.

India: Worldwide. Residents are taxed on their worldwide income while non-residents are taxed only on their India-source income. Non-residents are also taxed on income accruing abroad if it is from a business controlled in India or is from a profession established in India.

Indonesia: Worldwide. Residents are subject to tax on their worldwide income. Non-residents are generally subject to tax only on their Indonesian-source income. Individuals present in Indonesia for more than 182 days in a 12-month period are deemed residents.

Japan: Worldwide. Permanent residents are taxed on their worldwide income, and non-residents are taxed only on their Japan-source income. Non-permanent residents are taxed on Japan-source income plus the part of non-Japan source income that is paid in Japan or remitted to Japan. Individuals who stay in Japan for more than five years within the preceding 10 years are considered permanent residents.

Republic of Korea: Worldwide. Citizens and non-Korean residents who have stayed in Korea for longer than five years during the last 10-year period are taxed on their worldwide income. Non-residents are taxed only on their Korean-source income.

Macau: Territorial. Residence and/or domicile is irrelevant for tax purposes. Taxpayers pay tax only on Macau-source income. A professional tax is levied on anyone who receives income from services performed in Macau. 
Malaysia: Territorial. Residents and non-residents are subject to tax only on income derived from Malaysia.

Mongolia: Worldwide. Mongolian permanent residents pay tax on worldwide income. Non-residents pay tax on income earned in Mongolia. A non-resident is an individual who has no residence in Mongolia and has not resided in the country for more than 183 days in a year.

Myanmar: Worldwide. Resident nationals are taxed on their worldwide income. Non-resident foreigners are taxed only on Myanmar-source income. Foreigners who reside in Myanmar for at least 183 days in a year are considered residents.

New Zealand: Worldwide. Residents are taxed on their worldwide income. Non-residents are taxed only on their income derived from New Zealand. Individuals who have a permanent place of abode in New Zealand or who are in New Zealand for 183 days or more in a 12-month period are considered residents.

Pakistan: Worldwide. Residents are subject to tax on their worldwide income, except for certain income under an agreement for avoidance of double taxation. Non-residents are subject to tax only on Pakistan-source income. An individual who is present in Pakistan for 183 days or more in a tax year is considered resident.

Papua New Guinea (PNG): Worldwide. Residents are taxed on their worldwide income. Non-residents are taxed on their PNG-source income. A resident is an individual whose domicile is in PNG, or who is present in PNG for more than 182 days in a year.

Philippines: Worldwide. Resident citizens are taxed on their worldwide income. Non-resident citizens or aliens are taxed only on their income from sources within the Philippines. Most expatriates are classified as non-resident aliens.

Singapore: Territorial. Income derived in Singapore is taxable to residents and non-residents. Income derived from sources outside of Singapore is taxable only if it is received in Singapore by a resident individual through a partnership in Singapore.

Sri Lanka: Worldwide. Residents are taxed on their worldwide income, and non-residents are taxed only on their Sri Lanka-source income. Individuals are treated as residents for tax purposes if they have been physically present in the country for 183 days or more during a tax year.

Taiwan: Territorial. Residents and non-residents are taxed on Taiwan-source income. Non-resident aliens residing in Taiwan for less than 90 days in a calendar year are subject to $18 \%$ withholding tax on salary received only from a Taiwan-registered entity. Non-resident aliens residing in Taiwan for more than 90 days but less than 183 days in a calendar year are subject to tax at a flat rate of $18 \%$ on Taiwan-source income regardless of where it is paid.

Thailand: Territorial. Residents and non-residents are taxed only on income from Thai-source income. An individual is considered a resident if he/she resides in Thailand for 180 days or more in a calendar year.

Timor-Leste: Worldwide. Residents are taxed on worldwide income, whereas non-residents are taxed only on income sourced in Timor-Leste.

Turkey: Worldwide. Residents are taxed on their worldwide income. Non-residents are taxed only on Turkish-source earnings. Individuals with uncertain residence status in Turkey but have lived in Turkey uninterruptedly for more than six months in a calendar year are deemed residents. 
Uzbekistan: Worldwide. Residents are taxed on their worldwide income while non-residents are taxed only on their income from activities in Uzbekistan. Anyone who is present in the country for 183 days or more in a calendar year is considered a resident.

Vietnam: Worldwide. Residents (individuals who live in the country for 183 days or more in a calendar year) are subject to tax on their worldwide income. Non-residents are subject to tax only on their Vietnamese-source income.

\section{Europe}

Armenia: Worldwide. Residents are taxed on their worldwide income. Non-residents are taxed only on Armenian-source income. Individuals whose center of vital interests is in Armenia, or who reside in Armenia for 183 days or more in a year are considered residents.

Austria: Worldwide. Residents are subject to tax on their worldwide income. Non-residents are subject to tax only on income from certain Austrian sources. Individuals are considered residents if they reside in the country for more than six months.

Belarus: Worldwide. Residents are taxed on their worldwide income. Non-residents are taxed only on Belarus-source income. Individuals who reside in Belarus for 183 days or more in a year are deemed residents.

Belgium: Worldwide. Residents are taxed on their worldwide income, and non-residents are taxed only on their income earned or collected in Belgium. Residents are those who have established their domicile or their center of economic interests is in Belgium.

Bosnia/Herzegovina: Worldwide. Residents are subject to tax on their worldwide income, whereas non-residents pay tax only on income sourced in Bosnia/Herzegovina. Residents are individuals who are in Bosnia/Herzegovina for 183 days or more in a year.

Bulgaria: Worldwide. Residents are taxed on their worldwide income while non-residents are taxed only on income from Bulgarian sources. Regardless of their citizenship, resident status is for anyone who is permanently domiciled in the country or has resided in Bulgaria for more than 183 days in a 12-month period.

Croatia: Worldwide. Residents and individuals who reside in Croatia for more than 183 days within a period of two calendar years must pay tax on their worldwide income. Others who reside in Croatia for less than 183 days pay tax only on their Croatian-source income.

Cyprus: Worldwide. Residents and individuals who reside in Cyprus for more than 183 days in a calendar year pay tax on their worldwide income. Non-residents pay tax only on their income derived from sources in Cyprus.

Czech Republic: Worldwide. Residents, which include individuals who spend 183 days or more in a calendar year or have a permanent place of abode in the Czech Republic, are taxed on their worldwide income. Non-residents are generally taxed only on Czech-source income.

Denmark: Worldwide. Residents which include individuals who reside in Denmark for more than six consecutive months are charged with a full tax liability on their worldwide income. Non-residents are generally subject to tax only on their Danish-source income.

Estonia: Worldwide. Residents are taxed on worldwide income. Non-residents are taxed only on Estonian-source income. Residents include individuals who have a permanent residence in Estonia, who stay in Estonia for more than 182 days in a 12-month period, or who are Estonian public servants sent abroad on assignment. 
Faroe Islands: Worldwide. The taxation rules for Faroe Islands are the same as those for Denmark. There are special rules for non-residents who participate in oil and gas exploration activities in Faroe Islands; they are taxed at a flat rate of $35.5 \%$.

Finland: Worldwide. Residents are taxed on their worldwide income; individuals who reside in Finland for more than six months in a calendar year are deemed to be residents. Residents are taxed according to progressive tax rates. Non-residents are generally taxed only on their Finnish-source income and are taxed at flat rates. Expatriates whose work require a special knowledge and reside in Finland for 6-24 months are taxed at a flat rate of $35 \%$.

France: Worldwide. Individuals who are domiciled in France are generally subject to tax on their worldwide income, and individuals who are not domiciled in the country are subject to tax only on their income derived in France or, in some instances, on imputed income. If one or more of the four criteria is met, the individual is deemed to be domiciled in France.

Georgia: Territorial. Individuals are exempt from tax on income that does not have a Georgian source.

Germany: Worldwide. Residents are taxed on their worldwide income while non-residents are taxed only on their German-source income (usually by withholdings). A person is considered to be a resident if he/she is physically present in the country for more than six months in a calendar year.

Gibraltar: Territorial. Only income accruing in or derived from Gibraltar are taxed.

Greece: Worldwide. Permanent residents are taxed on their worldwide income, and non-residents are generally taxed only on their Greek-source income.

Guernsey, Channel Islands: Worldwide. "Principally resident” and "solely resident” individuals are subject to tax on their worldwide income. "Resident only" individuals either pay tax on their worldwide income or alternatively pay tax on Guernsey-source income and pay a set charge of GBP 30,000 in respect of non-Guernsey source income. Individuals who are in Guernsey for 183 days or more are considered "principally residents". Those who are in Guernsey for 91 days or more and not in any other jurisdiction for 91 days or more are "solely residents". Individuals spending between 91 and 183 days in Guernsey are considered "resident only". Individuals are also considered "resident only" if they spend 35 days in a year and an aggregate of 365 days over the preceding four years in Guernsey.

Hungary: Worldwide. Residents are taxed on their worldwide income, and non-residents are taxed only on their Hungarian-derived income. A person is deemed to be a resident for tax purposes if that person has a permanent home, center of vital interests, or habitual place of staying in Hungary.

Iceland: Worldwide. Residents are subject to tax on their worldwide income. Non-residents are subject to national and municipal tax only on their income from Iceland. Non-residents are individuals who stay in Iceland for 183 days or less in any 12-month period.

Ireland: Worldwide. Residents domiciled in Ireland are taxed on their worldwide income. Residents who are not domiciled in Ireland are subject to worldwide income to the extent that it is remitted into Ireland. Non-residents are taxed only on Irish-source income. An individual is deemed to be a resident if he/she resides in Ireland for 183 days or more in a calendar year or for 280 days or more within a two-year period.

Isle of Man: Worldwide. Residents are taxed on their worldwide income, and non-residents are normally taxed only on income derived from Isle of Man. Generally, anyone who resides in the country for six months or more is deemed to be a resident for tax purposes. 
Italy: Worldwide. Generally, residents are taxed on their worldwide income, and non-residents are taxed only on their Italian-source income. Individuals who have resided or have been domiciled in Italy for more than 183 days in a calendar year are considered residents. There is an anti-abuse law that requires Italian citizens who move to countries considered "tax havens" to be deemed as residents for tax purposes.

Jersey, Channel Islands: Worldwide. Residents who are ordinarily residents in Jersey are subject to tax on their worldwide income. Residents who are not ordinarily residents in Jersey are taxed on Jersey-source income, and overseas income is subject to tax only if it is remitted to Jersey. Non-residents are subject to tax on Jersey-source income except for some specific exemptions.

Kazakhstan: Worldwide. Residents are taxed on their worldwide income. Non-residents are taxed only on their Kazakhstan-source income. Individuals who are present in Kazakhstan for 183 or more days in a 12-month period, or whose center of vital interest is in Kazakhstan are deemed residents.

Liechtenstein: Worldwide. Residents are taxed on their worldwide income, and non-residents are normally taxed only on their income derived from the country. A person is considered a resident if he/she resides in the country and performs a gainful activity (employed or self-employed).

Lithuania: Worldwide. Residents are subject to tax on worldwide income, with certain exceptions. Non-residents are taxed only on specific income sourced in Lithuania. There are specific criteria for individuals to be considered residents: permanent place of residence is in Lithuania; personal, social, or economic interests are in Lithuania; staying in Lithuania for 183 days or more in a tax year; staying in Lithuania for 280 days or more during a number of successive tax periods and staying for 90 or more days during one of such periods; citizens who work in another country but have their costs of living covered from the state or municipal budgets of Lithuania.

Luxembourg: Worldwide. Residents are taxed on their worldwide income, and non-residents are taxed only on their income derived from Luxembourg. Anyone who resides in the country for more than six months within a 12-month period is considered a resident.

Macedonia: Worldwide. Residents are taxed on their worldwide income, whereas non-residents are taxed on their income derived in Macedonia. Residents are individuals who have a permanent place of residence in Macedonia, or have stayed in Macedonia for 183 days or more in any 12-month period.

Malta: Worldwide. Taxpayers who are both domiciled and ordinarily residents in Malta pay tax on their worldwide income. Taxpayers who are not domiciled or not ordinarily residents in Malta pay tax only on income arising in Malta and any foreign income remitted to Malta. Non-residents pay tax only on Malta-source income. There are few specific rules relating to residence, ordinary residence, or domicile.

Montenegro: Worldwide. Residents are subject to tax on their worldwide income. Non-residents are taxed on certain income sourced in Montenegro. Residents are individuals who have domicile in Montenegro, have a center of personal and economic activities in Montenegro, or spend 183 days or more in Montenegro.

Netherlands: Worldwide. Residents are taxed on their worldwide income, and non-residents are taxed only on income derived from specific sources in the Netherlands. Facts and circumstances determine a person's residence.

Norway: Worldwide. Residents are subject to tax on their worldwide income while non-residents are taxed only on their compensation related to Norwegian sources. Anyone who resides in the country for more than 183 days is considered a resident. 
Poland: Worldwide. Residents pay personal income tax on their worldwide income. Non-residents are taxed only on income earned in Poland or from sources located in Poland. Anyone who has a center of personal or business interests in Poland or spends more than 182 days in a fiscal year in Poland is considered a resident.

Portugal: Worldwide. Residents are taxed on their worldwide income. Non-residents are taxed only on their Portuguese-source income at a flat rate of $25 \%$. Generally, a person who resides in Portugal for more than 183 days in a calendar year, or maintains a habitual residence in Portugal is deemed to be a resident.

Romania: Worldwide. Residents are taxed on their worldwide income, except for salary income for work performed in other countries. Non-residents are taxed, generally, only on their Romanian-source income. Individuals are usually considered residents if they reside in the country for more than 183 days in a calendar year, are domiciled in Romania, or have their center of vital interests in Romania.

Russian Federation: Worldwide. Residents are taxed on their worldwide income. Non-residents are taxed only on their income received from sources in Russia. An individual is considered a resident if he/she is physically present in Russia for 183 days or more in a calendar year.

Serbia: Worldwide. Residents are subject to tax on their worldwide income. Non-residents are taxed on Serbian-source income as well as worldwide income related to work in/for Serbia. Residents include those individuals whose center of business and vital interests is in Serbia, or have been in Serbia for 183 days or more within a taxation year.

Slovak Republic: Worldwide. Residents are taxed on their worldwide income whether or not the income is remitted to the Slovak Republic. Non-residents are taxed only on their Slovak-source income. Individuals who reside in the country for more than 183 days in a calendar year, or have a permanent residence in the Republic are deemed to be residents.

Slovenia: Worldwide. Residents are taxed on their worldwide income. Non-residents are usually taxed only on their Slovenian-source income. Normally, a person who has a formal or actual residential tie with Slovenia is considered a resident.

Spain: Worldwide. Residents are taxed on their worldwide income; non-residents are taxed only on their Spanish-source income, capital gains, and wealth in Spain. An individual who resides in Spain for more than 183 days in a calendar year or has Spain as his/her center of economic interest is deemed to be a resident.

Sweden: Worldwide. Residents are taxed on their worldwide income. Non-residents are normally taxed only on Swedish-source income. Individuals who reside in Sweden for more than six months continuously are considered residents. Generally, Swedish citizens and foreigners who have resided in Sweden for 10 years are deemed to be residents unless they can prove that all important ties with Sweden have been broken.

Switzerland: Worldwide. Residents, including persons who intend to have gainful employment for more than 30 days, or reside more than 90 days without having gainful employment in Switzerland, are subject to tax on their worldwide income and wealth. Non-residents are taxed only on limited sources of Swiss income.

Turkmenistan: Worldwide. Residents are subject to tax on their worldwide income, while non-residents are taxed only on income sourced in Turkmenistan. Individuals who are in the country for 183 days or more in a calendar year are deemed residents.

Ukraine: Worldwide. Residents are taxed on their worldwide income; non-residents are taxed only on income from Ukraine sources. There is a somewhat complicated set of rules in the definition of a resident. 
United Kingdom: Worldwide. Residents are taxed on their worldwide income and capital gains. Non-residents are normally taxed on their U.K. income (but usually not on capital gains). A person who is a resident but is not domiciled in the U.K. normally pays taxes only if the income is received in the U.K. There are several specific tax laws relating to domicile and residency. Generally, individuals who reside in the U.K. for more than 183 days in the calendar year are considered residents.

\section{Africa/Middle and Near East}

Algeria: Worldwide. Residents are subject to tax on their worldwide income, while non-residents pay tax only on Algerian-source income. Individuals who have been in Algeria for 183 days or more in a year are considered residents.

Angola: Territorial. Only income earned in Angola is subject to personal income tax. Residency is therefore irrelevant.

Bahrain: None. There is no individual income tax.

Botswana: Territorial. Residents are taxed on income within Botswana. Income for services performed outside the country is deemed to be from a Botswana source if the services are incidental to employment in Botswana. Non-residents are taxed only on income earned in Botswana. A person is considered a resident if he/she resides in the country for 183 days or more in a calendar year.

Republic of Cameroon: Worldwide. All individuals with a fiscal domicile in the country are taxed on their worldwide income. Individuals of foreign nationality who are present in Cameroon for more than 183 days in a calendar year are considered as domiciled in Cameroon unless they can prove that the job they perform in the country is of an accessory nature.

Chad: Worldwide. Residents are subject to tax on their worldwide income. Non-residents are taxed only on income from activities in Chad. Individuals who have a dwelling place in Chad, live in Chad for more than 183 days in a year, or have center of economic interests in Chad are deemed residents.

Democratic Republic of Congo: Territorial. Residents and non-residents are taxed only on professional, commercial, and employment activities in Congo; on rental of real estate in Congo; and on income from domestic investments.

Republic of Congo: Worldwide. Residents are taxed on their worldwide income, whereas non-residents are taxed only on their Congolese income. Individuals whose principal residence is in the Republic of Congo are considered residents.

Egypt: Worldwide. Residents are taxed on their worldwide income. Non-residents are taxed only on their income earned in Egypt. A resident is a person who has a permanent home in Egypt or resides in Egypt for more than 183 days within 12 months. An Egyptian who performs duties abroad but receives income from an Egyptian treasury is also deemed resident.

Gabon: Territorial. All individuals are subject to tax on all income received as remuneration for any activity carried out in Gabon and on revenues having origin in Gabon.

Ghana: Worldwide. Residents are taxed on their worldwide income. Non-residents are taxed only on income derived in Ghana. A person who has a permanent home in Ghana, or resides in the country for 183 days or more in a 12-month period is deemed to be a resident. 
Iran: Worldwide. Residents are taxed on their worldwide income. Non-residents are normally taxed only on their Iranian-source income. People who reside in Iran for more than six months in a calendar year are deemed to be residents.

Iraq: Worldwide. Residents are subject to tax on their worldwide income. Non-residents are taxed on their income derived from Iraq. Individuals are considered residents if they stay in Iraq for four months continuously, or for six months scattered during the fiscal year.

Israel: Worldwide. Residents are taxed on their worldwide income. Non-residents are taxed only on their Israeli-source income and capital gains from assets situated in Israel. A tax resident is a person whose center of life is in Israel. There are several rules in the determination of "center of life" (including 183 days or more in a calendar year).

Ivory Coast: Worldwide. Residents are taxed on their worldwide income. Non-residents are normally taxed only on their Ivory Coast income.

Jordan: Territorial. Any income incurred in or from Jordan, for any person, regardless of the place of payment, is subject to tax.

Kenya: Worldwide. Residents are taxed on their worldwide income. Non-residents are normally taxed only on their Kenyan-source income. A resident is a person who has a permanent home in Kenya and resides in the country for any period of time in a tax year, or a person who resides in Kenya for 183 days or more in any tax year or an average of more than 122 days within three consecutive tax years.

Kuwait: None. There is no income tax.

Lebanon: Worldwide. In general, residents are taxed on their worldwide income. Individuals are also taxed on income for services executed in Lebanon, or for services that have contributed to the welfare of a company located in Lebanon even if the source of funding is outside Lebanon. In addition, taxes are due on income sourced in Lebanon regardless of residency or where the activities are carried out. There is no clear definition of residency. Nevertheless, individuals are considered residents if they have a fixed place of business in their name in Lebanon, or if they practice a profession or business activity in a normal manner in Lebanon.

Libya: Territorial. Libyans and foreign nationals are subject to tax only on income derived from employment in Libya.

Malawi: Territorial. Individuals are taxed only on Malawi-sourced income regardless of residence.

Mauritius: Worldwide. Residents are normally taxed on their worldwide income. However, income earned outside Mauritius is taxed only to the extent that it is received in Mauritius. Non-residents are normally taxed only on income derived from Mauritius. An individual is a resident if he/she is domiciled in the country or resides in the country for 183 days or more in a calendar year or resides in the country for 270 days or more within a three-year period.

Morocco: Worldwide. Residents are subject to tax on their worldwide income. Non-residents are subject to tax only on Moroccan-source income. Individuals are deemed residents if they have a permanent home in Morocco, their center of economic interest is in Morocco, or if they stay in Morocco for 183 days or more within a 365-day period.

Mozambique: Worldwide. Residents are taxed on their worldwide income while non-residents are taxed on their income arising in Mozambique. A person is a resident if he/she resides in the country for more than 183 days in a calendar year or occupies a residence indicating intent to continue occupancy on a regular basis. Crew members of a vessel or an airplane registered in Mozambique are deemed to be residents. 
Republic of Namibia: Territorial. Residents and non-residents are taxed only on income derived or deemed to be derived from sources within Namibia.

Nigeria: Worldwide. Residents are taxed on their worldwide income. Non-residents are liable to tax in Nigeria if the duties of employment are wholly or partly performed in Nigeria, with exceptions. Individuals are considered residents if they are in Nigeria for at least 183 days in any 12-month period or they serve as diplomatic agents of Nigeria abroad.

Oman: None. There is no individual income tax.

Qatar: None. There is no personal income tax in Qatar.

Rwanda: Worldwide. Residents are taxed on their worldwide income. Non-residents are taxed only on their Rwandan-source income. Individuals are deemed residents if they have a permanent residence in Rwanda, have a habitual abode in Rwanda, are Rwandans representing Rwanda abroad, or stay in Rwanda for 183 days or more in a 12-month period.

Saudi Arabia: None. There is no individual income tax.

Senegal: Worldwide. Residents are taxed on their worldwide income. Non-residents are taxed on income sourced in Senegal if the work is performed in Senegal or the employer is established in Senegal. Residents are individuals who have permanent abode in Senegal, who spend more than 183 days a year in Senegal, or have their main professional activities in Senegal.

South Africa: Worldwide. Residents are taxed on their worldwide income. Non-residents are taxed only on their South African-source income. Persons are considered residents if they reside in South Africa for more than 91 days in the relevant tax year and each of the preceding five tax years, and also for more than 915 days in the preceding five tax years.

Swaziland: Territorial. Residents and non-residents are taxed only on income derived or deemed to be derived within Swaziland. The tax laws do not specifically define residency, but generally, anyone who is employed or operates a business in the country is considered a resident.

Tanzania: Worldwide. Residents are taxed on their worldwide income. Non-residents are taxed only on their Tanzanian-source income. A person is a resident if he/she has a permanent home in the country and resides in the country during any time of a tax year or resides in Tanzania for more than 183 days in a calendar year or resides an average of more than 122 days per year in a three-year period.

Tunisia: Worldwide. Residents are taxed on their net global income. Non-residents are taxed only on Tunisian-source income. Individuals are considered residents according to the Tunisian common law if they have their principal domicile in Tunisia, or if they stay in Tunisia for 183 days or more in a calendar year.

Uganda: Worldwide. Residents are taxed on their worldwide income. Non-residents are normally taxed only on their Ugandan-source income. A resident is an individual who has a permanent home in Uganda or resides in the country for 183 days or more in a 12-month period or resides in the country for an average of 122 days or more per year in a three-year period.

United Arab Emirates: None. There is no income tax.

Zambia: Territorial. Residents are taxed on Zambian-source income as well as foreign interest and dividends received. Non-residents are taxed only on Zambian-source income. Individuals who reside in the country for less than 183 days in a calendar year and have no plans to establish permanent residency in the country are treated as non-residents. 
Zimbabwe: Territorial. Residents and non-residents are all taxed on income sources derived in Zimbabwe. Non-residents are taxed only on income sources derived in Zimbabwe. There are no specific tax rules defining residency.

\section{Analyses and Comparisons}

This study reveals that the worldwide income approach (also known as the global tax system) for income tax purposes is more prevalent in usage than is the territorial income approach. The worldwide approach taxes income from all sources regardless of what country the income is derived while with the territorial approach, only income earned or received within a country's borders is taxable. Many countries use the worldwide approach for their citizens and/or residents but use the territorial approach for non-residents. There is some variation among the countries as to the definition of resident status versus non-resident status.

The primary focus of this research is to examine which countries (out of a total of 143 countries) normally use the worldwide taxation approach, which normally use the territorial approach, and what specific rules are applied in relation to these income approaches (especially concerning the countries' definitions of resident status versus non-resident status). This study reveals that 10 countries have no individual income tax, and thus for those nations the subject matter would be irrelevant.

Comparisons are made on a regional basis (Americas, Asia/Pacific Basin, Europe, and Africa/Middle and Near East). Table 1 shows the number of countries in each category. Table 1 also includes the number of countries that have no individual income taxes (making this subject matter irrelevant).

Based on the information in Table 1, the worldwide approach is much more prevalent (104 countries) than the territorial approach (30 countries). It is apparent that, generally speaking, the more developed nations utilize the worldwide approach while many of the less-developed or smaller countries tend to use the territorial approach. Interestingly, almost all of the European countries tax income on worldwide sources. Only two countries out of 47 (4.3\%) use territorial approach. In comparison, 11 out of 31 (35.5\%) in Americas, six out of 26 (23.1\%) in Asia/Pacific Basin, and 11 out of 39 (28.2\%) in Middle and Near East use the territorial approach. As a side note, all countries in Asia/Pacific Basin and Europe have individual income tax, whereas three countries in Americas (9.7\%) and six in Africa/Middle and Near East (15.4\%) have no individual income tax.

Table 1

Countries by Region in Each Tax Category

\begin{tabular}{lcccc}
\hline \multirow{2}{*}{ Region } & \multicolumn{3}{c}{ Number of countries } \\
\cline { 2 - 5 } & Worldwide & Territorial & None & Total \\
\hline Americas & 17 & 11 & 3 & 31 \\
Asia/Pacific Basin & 20 & 6 & 0 & 26 \\
Europe & 45 & 2 & 0 & 47 \\
Africa/Middle and Near East & 22 & 11 & 6 & 39 \\
Total & 104 & 30 & 9 & 143 \\
\hline
\end{tabular}

An important factor that could be relevant to someone who plans to work in another country on a temporary basis is how a particular country treats such an individual (resident or non-resident) for income tax purposes. There appears to be an abundant spectrum of rules relating to residency and domicile for tax purposes among the countries. For instance, in a lot of countries a resident is a taxpayer who lives in that country for 183 days or more during a year. In other countries, the time period is more than 183 days, six months, or some other 
length of time. Several countries have a two-year or three-year window. Some countries count the number of days in a calendar year, others use a 12-month period. The U.S. includes as residents for tax purposes anyone who is present in the country for at least 31 days in the current tax year and a total of 183 equivalent days during the current year and the previous two years.

Besides the duration of time a taxpayer is physically present in a country, other factors are also used by some countries to determine whether or not a taxpayer is considered a resident for tax purpose; for example, a taxpayer's center of vital interests, residential tie with the country, place of permanent/habitual dwelling.

\section{Conclusions}

As observed in this study, the worldwide income approach is significantly more prevalent throughout the world than the territorial approach. It seems that since many of the less-developed and smaller countries use the territorial approach, it would behoove those nations to consider the possibility of switching to the worldwide approach in order to increase their tax revenues. These nations may discover that such a switch could make a large difference in helping their economic growth. On the other hand, some of these countries may have only few taxpayers who earn taxable income other than domestic income; in these cases, it may not be very beneficial to change to a worldwide approach.

In relation to the worldwide approach, it is important to remember that taxpayers who have income from foreign sources may often be able to reduce their income taxes by utilizing foreign income exclusions, foreign tax credits, and/or foreign tax deductions. Such tax reductions are normally based on certain tax laws of a particular country and/or foreign tax treaties between that country and specific other nations.

Another factor to consider relative to the worldwide approach is the fact that a government may find it difficult to enforce the rule that a taxpayer must report income from worldwide sources for income tax purposes. Without a doubt, there are taxpayers who fail to report some or all of their foreign income (intentionally or unintentionally) or find ways to hide some or all of their earnings in bank accounts in tax-haven countries. The best solution to minimize their dilemma would be for governments to strictly enforce the rules by increased investigations and working with other countries through tax agreements and reciprocity.

\section{Reference}

Fay, J. (2002). Have individual income tax rates changed significantly throughout the world during the past decade? Oil, Gas, and Energy Quarterly, 50(3), 647-680.

KPMG. (n.d.). Individual income tax rates table. KPMG. Retrieved from https://home.kpmg.com/xx/en/home/services/tax/tax-tools-and-resources/tax-rates-online/individual-income-tax-rates-table.h $\mathrm{tml}$

Mendoza, E., Razin, A., \& Tesar, L. (1994). Effective tax rates in macroeconomics: Cross-country estimates of tax rates on factor incomes and consumption. Journal of Monetary Economics, 34(3), 297-323.

PricewaterhouseCoopers. $\quad$ (n.d.). Worldwide $\quad \operatorname{tax}$ summaries. PwC. Retrieved from https:/home.kpmg.com/xx/en/home/services/tax/tax-tools-and-resources/tax-rates-online/individual-income-tax-rates-table.html

Sabirianova, K., Buttrick, S., \& Duncan, D. (2009). Global reform of personal income taxation, 1981-2005: Evidence from 189 countries. Working Paper. Retrieved from https://papers.ssrn.com/sol3/papers.cfm?abstract_id=1091534

Shum, C., Fay, J., \& Lui, G. (2017). Individual income tax: A cross-continental comparison. World Journal of Social Sciences, 7(1), 66-90.

Wagstaff, A., van Doorslaerb, E., van der Burgb, H., Calongec, S., Christiansend, T., Citoni, G., ..., \& Winkelhake, O. (1999). Redistributive effect, progressivity and differential tax treatment: Personal income taxes in twelve OECD countries. Journal of Public Economics, 72(1), 73-98. 